\title{
Effect of Lime and Integrated Nutrient Management on Soybean under Rainfed Condition of Nagaland
}

\author{
Anniecia Lynrah and D. Nongmaithem ${ }^{*}$
}

Dept. of Agronomy, SASRD, Nagaland University, Medziphema, Nagaland (797 106), India

\section{Corresponding Author}

D. Nongmaithem

e-mail: debikanong@gmail.com

\author{
Article History \\ Article ID: AR1818 \\ Received in $5^{\text {th }}$ June, 2017 \\ Received in revised form $18^{\text {th }}$ September, 2017 \\ Accepted in final form $5^{\text {th }}$ October, 2017
}

\begin{abstract}
A field experiment was conducted in the Experimental Research Farm of School of Agricultural Sciences and Rural Development (SASRD), Nagaland University during the kharif season of 2015 to study the effect of lime and integrated nutrient management on soybean under acidic soil of Nagaland. The results revealed that application of lime @ $1.5 \mathrm{t} \mathrm{ha}^{-1}$ gave highest values of growth and yield attributes. The number of primary branches plant ${ }^{-1}$, dry weight of plant, crop growth rate, fresh weight of nodules plant ${ }^{-1}$, number of pods plant ${ }^{-1}$, pod length were obtained with the application of lime @1.5 t ha-1 and hence recorded highest seed $\left(2.71 \mathrm{t} \mathrm{ha}^{-1}\right)$ and stover yield $\left(2.79 \mathrm{t} \mathrm{ha}{ }^{-1}\right)$. The uptake of NPK by soybean was also found to be highest under application of lime @ $1.5 \mathrm{t} \mathrm{ha}^{-1}$. Among the nutrient sources, application of $50 \%$ RDF+Rhizobium @ $20 \mathrm{~g} \mathrm{~kg}^{-1}$ seed+Phosphate solubilising bacteria (PSB) @20 g kg-1 seed gave the best results in terms of growth attributes and recorded the highest yield and nutrient uptake by the crop which was followed by 50\% RDF+FYM @ $5 \mathrm{t}$ ha ${ }^{-1}+$ Vermicompost @ $2 \mathrm{t} \mathrm{ha}^{-1}$.The treatment combination of $1.5 \mathrm{t} \mathrm{ha}^{-1}$ of lime with $50 \%$ RDF+Rhizobium @ $20 \mathrm{~g} \mathrm{~kg}^{-1}$ seed+Phosphate solubilising bacteria (PSB) $@ 20 \mathrm{~g} \mathrm{~kg}^{-1}$ seed gave the highest gross and net return with B:C ratio of 1.83 among all the treatment combinations and thus was found to be most economical treatment for soybean under rainfed condition of Nagaland.
\end{abstract}

Keywords: Lime, integrated nutrient management, soybean, acidic soil, yield

\section{Introduction}

Among the major constraints in soybean production, one of the factors hindering efficient fertilizer management in north eastern region of India particularly is acidic soil. Nutrient deficiencies such as $\mathrm{P}, \mathrm{Ca}, \mathrm{Mg}, \mathrm{Mo}$ and $\mathrm{K}$ is a common phenomena associated with soil acidity. A decrease in soil pH increases the concentration of $\mathrm{Fe}$ and $\mathrm{Al}$ ions among other cations such as $\mathrm{Mn}^{4+}, \mathrm{H}^{+}$and $\mathrm{Cu}^{2+}$ in soil solution (Verde et al., 2013; Kisinyo et al., 2013). In addition to this, soil acidity is the limiting factor for symbiotic nitrogen fixation and affects the survival and persistence of nodule bacteria in soil, as well as reducing nodulation. Nodulation impairment is commonly noticed when legumes are grown on acid soil (Mohammadi et al., 2012). The toxic effect of aluminium and manganese along with calcium and phosphorous deficiency in acidic soil inhibit Rhizobium growth and root infection resulting in symbiotic failure (Bambara and Ndakidemi, 2010). Thus, for economically feasible and sustainable agricultural production in the acid soils, liming at appropriate dose is required. Liming, which has been documented as a conventional way of amending acidic soils can benefit soybean farmers (Kiplagat et al., 2010) as it raises the $\mathrm{pH}$ since optimum soil $\mathrm{pH}$ for soybean is $5.5-6$. It not only neutralize the toxic effect of hydrogen, aluminium and manganese but also supply calcium and magnesium, raising the $\mathrm{pH}$ of the soil at which Bradyrhizobium acts best and an important plant macronutrient $P$ is made available to them (Guo et al., 2009).

The productivity of soybean is low particularly in Nagaland due to nutritional deficiency, imbalanced fertilization and use of local cultivars (Bhattacharjee et al., 2011). Inadequate fertilizer use and emergence of multiple-nutrient deficiencies due to poor recycling of organic resources and unbalanced use of fertilizers are important factors to be considered for low productivity of soybean (Chaturvedi et al., 2010). Although north east region of India has a potential for bumper agricultural production, the economy in fertilizers use, sustaining soil health and yields of crops could be achieved only by conjunctive use of fertilizers, organics and biofertilizers. It is now increasingly being realized that integrated soil fertility management involving combinations of microbial inoculants, inorganic and organic fertilizers are essential to sustain productivity of acid soil and maintain soil health and biodiversity for the long run (Ellafi et al., 2011). To successfully grow field crops on acid soils, liming alone or in combination 
with mineral and organic fertilization, is recommended worldwide (Uzoho et al., 2010). It has also been reported that essential nutrients are available to the plants and biological activity in soils are generally greatest at intermediate $\mathrm{pH}$ at which organic matter break down and release of essential nutrients like N, P and S is enhanced. Chao et al., 2014 also reported that application of lime, organic matter and fertilizers application reduced soil acidity, Al toxicity and nutrient deficiency. Therefore, keeping in view the deteriorating soil nature due to over use of synthetic chemicals along with the need to ameliorate acidic soil particularly in Nagaland condition as well as taking into consideration the importance of soybean in the economy of the state, it is necessary to find the need for liming acidic soil with optimum nutrient supply for the proper growth of soybean.

\section{Materials and Methods}

A field experiment was carried out at School of Agricultural Sciences and Rural Development (SASRD), Nagaland University during the period of July to September 2015. The experimental site was located at an altitude of $25^{\circ} 45^{\prime} 43^{\prime \prime} \mathrm{N}$ latitude and $95^{\circ} 53^{\prime} 04^{\prime \prime} \mathrm{E}$ longitude at an elevation of $310 \mathrm{~m}$ above mean sea level. The experimental design was split plot design (SPD) with three replications. The main plot treatments consists of four levels of lime: $\left(\mathrm{L}_{1}\right): 0 \mathrm{t} \mathrm{ha}{ }^{-1},\left(\mathrm{~L}_{2}\right): 0.5 \mathrm{t} \mathrm{ha}^{-1},\left(\mathrm{~L}_{3}\right): 1.0 \mathrm{t} \mathrm{ha}^{-1}$ and $\left(\mathrm{L}_{4}\right): 1.5 \mathrm{t} \mathrm{ha}{ }^{-1}$ while the sub-plot treatments consists of four sources of nutrients: $\left(\mathrm{N}_{1}\right): 100 \% \mathrm{RDF},\left(\mathrm{N}_{2}\right)$ : $50 \% \mathrm{RDF}+\mathrm{FYM}$ @ 5 t ha $^{-1}+$ Vermicompost @ 2 tha $^{-1},\left(N_{3}\right): 50 \%$ RDF+Rhizobium @ $20 \mathrm{~g} \mathrm{~kg}^{-1}$ seed+Phosphate solubilising bacteria (PSB) @ 20 $\mathrm{g} \mathrm{kg}^{-1}$ seed and $\left(\mathrm{N}_{4}\right)$ : FYM @ 5 t ha-1+Vermicompost @ $2 \mathrm{t} \mathrm{ha}$ ${ }^{1}+$ Rhizobium @ $20 \mathrm{~g} \mathrm{~kg}^{-1}$ seed + Phosphate solubilising bacteria (PSB) @ $20 \mathrm{~g} \mathrm{~kg}^{-1}$ seed. Soybean variety JS 95-60 was sown at a spacing of $40 \times 10 \mathrm{~cm}^{2}$ and the recommended package of practices were followed. The soil was sandy loam and acidic in reaction ( $\mathrm{pH} 4.7)$. The initial soil oxidizable organic carbon was $1.2 \%, 109 \mathrm{~kg} \mathrm{ha}^{-1}$ mineralizable nitrogen, $200 \mathrm{~kg} \mathrm{ha}^{-1}$ available potassium, and $7.84 \mathrm{~kg} \mathrm{ha}^{-1}$ available phosphorus. Fertilizers were applied uniformly to all plots at recommended rates $\left(20 \mathrm{~kg} \mathrm{~N} \mathrm{ha}^{-1}, 80 \mathrm{~kg} \mathrm{P}_{2} \mathrm{O}_{5} \mathrm{ha}^{-1}\right.$ and $60 \mathrm{~kg} \mathrm{~K}_{2} \mathrm{O} \mathrm{ha-1}$. The data related to each character were analyzed statistically by applying the techniques of analysis of variance as described by Cochran and Cox, 1957 and the significant of different source of variations was tested using Fisher Schedecor ' $F$ ' test at 0.05 level of probability.

\section{Results and Discussion}

\subsection{Effect of lime}

The highest number of primary branches plant ${ }^{-1}$, dry weight of plant, crop growth rate, fresh weight of nodules plant ${ }^{-1}$, number of pods plant ${ }^{-1}$ and pod length were recorded with the application of lime @ $1.5 \mathrm{t} \mathrm{ha}^{-1}$. The result is in conformity with the findings of Rakesh et al. (2014). The increase in crop growth rate with liming may result from better availability of nutrients due to moderation of soil reaction. Workneh et al. (2013) also reported that liming increased the weight of nodule plant ${ }^{-1}$ which might be because of creation of better soil environment for the activity of soybean nodulating bacteria existing in that soil. Okpara et al., 2007; Bekere et al., 2013 also reported that liming significantly increased nodule number, nodule volume and nodule dry weight plant ${ }^{-1}$ compared to un-limed treatments (Table 1).

Table 1: Effect of treatments on no. of primary branches plant $^{-1}$, dry weight of plant (g plant ${ }^{-1}$ ), crop growth rate (g $\left.\mathrm{m}^{-2} \mathrm{~d}^{-1}\right)$, nodule fresh weight (mg plant $\left.{ }^{-1}\right)$, no. of pods plant ${ }^{-1}$ and pod length $(\mathrm{cm})$

\begin{tabular}{lcccccc}
\hline Treatments & NPBP & DWP & CGR & NFW & NPP & PL \\
\cline { 1 - 4 } $\mathrm{L}_{1}$ & & & & & & \\
$\mathrm{~L}_{2}$ & 1.88 & 41.75 & 0.047 & 128 & 18.40 & 3.24 \\
$\mathrm{~L}_{3}$ & 2.32 & 45.67 & 0.050 & 130 & 21.37 & 4.11 \\
$\mathrm{~L}_{4}$ & 2.89 & 53.45 & 0.060 & 131 & 27.04 & 4.19 \\
$\mathrm{SEm} \pm$ & 3.21 & 69.29 & 0.080 & 140 & 30.26 & 6.00 \\
$\mathrm{CD}(p=0.05)$ & 0.51 & 7.59 & 0.011 & 5.67 & 2.71 & 0.33 \\
$\mathrm{INM}$ & & & & & & \\
\hline $\mathrm{N}_{1}$ & 2.46 & 49.29 & 0.055 & 23.02 & 4.2 & 132 \\
$\mathrm{~N}_{2}$ & 2.57 & 49.42 & 0.056 & 25.25 & 4.53 & 134 \\
$\mathrm{~N}_{3}$ & 3.31 & 62.83 & 0.071 & 26.35 & 4.77 & 135 \\
$\mathrm{~N}_{4}$ & 1.96 & 48.63 & 0.055 & 22.48 & 4.04 & 128 \\
$\mathrm{SEm} \pm$ & 0.17 & 3.75 & 0.004 & 1.85 & 0.93 & 0.12 \\
$\mathrm{CD}(p=0.05)$ & 0.50 & 10.97 & 0.012 & 5.47 & 2.69 & 0.34 \\
\hline
\end{tabular}

NPBP: No. of primary branches plant ${ }^{-1}$; DWP: Dry weight of plant; CGR: Crop growth rate; NFW: Nodule fresh weight; NPP: No. of pods plant ${ }^{-1}$; PL: Pod length $(\mathrm{cm}) ; L_{1}$ : 0 t ha ${ }^{-1}, \mathrm{~L}_{2}: 0.5 \mathrm{t} \mathrm{ha}^{-1}$; L3: $1.0 \mathrm{t} \mathrm{ha}^{-1}$; L4: 1.5 t ha-1 $^{-1} \mathrm{~N}_{1}: 100 \%$ RDF; $\mathrm{N}_{2}: 50 \%$ RDF+FYM @ 5 t ha ${ }^{-1}+$ Vermicompost @ $2 \mathrm{t}$ ha-1 $\mathrm{N}_{3}: 50 \%$ RDF+Rhizobium @ $20 \mathrm{~g} \mathrm{~kg}^{-1}$ seed+Phosphate solubilising bacteria (PSB) @ $20 \mathrm{~g} \mathrm{~kg}^{-1}$ seed, $\mathrm{N}_{4}$ : FYM @ 5 t ha-1+Vermicompost @ 2 t ha ${ }^{-1}+$ Rhizobium @ 20 g kg $^{-1}$ seed+Phosphate solubilising bacteria (PSB) @ $20 \mathrm{~g} \mathrm{~kg}^{-1}$ seed

Wijanarko et al. (2016) also reported that liming increased number of pod plant ${ }^{-1}$. Highest seed yield was recorded with application of $1.5 \mathrm{t} \mathrm{ha}^{-1}$ of lime which was at par with $1.0 \mathrm{t}$ $\mathrm{ha}^{-1}$ of lime (Table 2 ). The increase in yield may be due to the neutralization of exchangeable $\mathrm{Al}^{3+}$ ions and increase in available $\mathrm{Ca}^{2+}$ which in turn resulted in excellent seed filling. The highest stover yield was recorded with the application of $1.5 \mathrm{t} \mathrm{ha}^{-1}$ of lime. This may be due to improvement in soil $\mathrm{pH}$ and other physico-chemical properties of soil that increases plant availability of soil nutrients. This is also similarly reported by Ranjit et al. (2007). On the other hand, no application of lime gave the lowest stover yield which may be due to the low soil nutrient status and also due to poor activity of soil micro-organisms as affected by soil acidity. Application of 1.5 
Table 2: Effect of treatments on seed yield $\left(\mathrm{t} \mathrm{ha}^{-1}\right)$, stover yield ( $\left.\mathrm{t} \mathrm{ha} \mathrm{C}^{-1}\right), \mathrm{N}$ uptake by plant $\left(\mathrm{kg} \mathrm{ha}^{-1}\right), \mathrm{P}$ uptake by plant $\left(\mathrm{kg} \mathrm{ha}^{-1}\right)$ and $\mathrm{K}$ uptake by plant $\left(\mathrm{kg} \mathrm{ha}^{-1}\right)$

\begin{tabular}{|c|c|c|c|c|c|}
\hline Treatments & $S Y^{*}$ & SY & $\begin{array}{l}\mathrm{N} \text { uptake } \\
\text { by plant }\end{array}$ & $\begin{array}{l}\text { P uptake } \\
\text { by plant }\end{array}$ & $\begin{array}{l}\text { K uptake } \\
\text { by plant }\end{array}$ \\
\hline \multicolumn{6}{|l|}{ Lime } \\
\hline $\mathrm{L}_{1}$ & 1.52 & 1.87 & 64.34 & 14.37 & 34.14 \\
\hline $\mathrm{L}_{2}$ & 1.81 & 2.14 & 86.17 & 17.66 & 44.42 \\
\hline $\mathrm{L}_{3}$ & 2.21 & 2.57 & 114.47 & 30.48 & 67.22 \\
\hline $\mathrm{L}_{4}$ & 2.71 & 2.97 & 147.51 & 39.13 & 92.05 \\
\hline SEm \pm & 0.03 & 0.07 & 1.73 & 1.24 & 2.11 \\
\hline $\mathrm{CD}(p=0.05)$ & 0.10 & 0.23 & 6.01 & 4.30 & 7.33 \\
\hline \multicolumn{6}{|l|}{ INM } \\
\hline$N_{1}$ & 2.05 & 2.36 & 99.65 & 24.09 & 56.71 \\
\hline $\mathrm{N}_{2}$ & 2.07 & 2.43 & 105.81 & 26.40 & 61.37 \\
\hline $\mathrm{N}_{3}$ & 2.14 & 2.46 & 112.32 & 28.69 & 64.66 \\
\hline $\mathrm{N}_{4}$ & 2.00 & 2.29 & 94.71 & 22.46 & 55.09 \\
\hline SEm \pm & 0.02 & 0.04 & 1.77 & 0.88 & 1.93 \\
\hline $\mathrm{CD}(p=0.05)$ & 0.05 & 0.12 & 5.18 & 2.58 & 5.65 \\
\hline
\end{tabular}

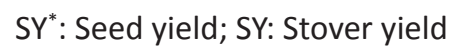

$\mathrm{t} \mathrm{ha} \mathrm{a}^{-1}$ of lime recorded the highest nitrogen uptake $(147.51 \mathrm{~kg}$ $\left.\mathrm{ha}^{-1}\right)$, phosphorus uptake ( $\left.39.13 \mathrm{~kg} \mathrm{ha}^{-1}\right)$ and potassium uptake $\left(92.05 \mathrm{~kg} \mathrm{ha}^{-1}\right)$ while the lowest uptake of NPK was observed with no lime treatment. The increase in phosphorus uptake by soybean on liming might be due to the increase in the available soil phosphorus content as it breaks the aluminum and iron phosphates in the soil.

\subsection{Effect of integrated nutrient management}

There was significant effect on number of primary branches plant $^{-1}$, dry weight of plant, crop growth rate, fresh weight of nodules plant ${ }^{-1}$, number of pods plant ${ }^{-1}$ and pod length due application of different sources of nutrients where highest values were observed with 50\% RDF+Rhizobium @ $20 \mathrm{~g}$ $\mathrm{kg}^{-1}$ seed+Phosphate solubilising bacteria (PSB) @ $20 \mathrm{~g} \mathrm{~kg}^{-1}$ seed. Higher availability of nutrients due to the combined application of organic and inorganic nutrients increased the dry matter production with the increase in the number of branches plant ${ }^{-1}$. Nagar and Dadheech (2002) also observed that increased number of branches in soybean when the crop was dually inoculated with Bradyrhizobium and PSB. Thenua et al., 2010 reported that application of biofertilizers resulted in improved nodulation and resulted in supplying higher amount of nitrogen for growth and yield attributes which in turn helped to realize higher growth parameter and dry matter of soybean. Increase in dry matter accumulation due to combined application of microbial inoculants was also earlier reported in other legume crops like black gram and green gram (Kalita et al., 2006). Walpola and Yoon (2013) also reported that inoculation of Rhizobium and PSB increased the weight of nodules in legumes. Increased activity of microorganisms in root zone due to inoculation was reflected in the significant improvements in growth parameters and this better growth might have possibly paved the way for significant improvements in yield contributing characters (Bodkhe and Syed, 2014). Among the different sources of nutrients, highest seed and stover yield was recorded with $50 \%$ RDF+Rhizobium @ $20 \mathrm{~g} \mathrm{~kg}^{-1}$ seed+Phosphate solubilising bacteria (PSB) @ $20 \mathrm{~g} \mathrm{~kg}^{-1}$ seed. Integration of fertilizers along with rhizobium and PSB was found to record highest values in the growth and yield attributes which ultimately was reflected in the yield of soybean. This may be due to the more availability of macro nutrients from the fertilizers along with that augmented through biofertilizers. Tomar (2011); Nagaraju and Mohankumar (2013) also reported that plant growth and yield of crop is enhanced due to Rhizobium as it is known to promote growth promoting substances like IAA, Gibberellins and cytokinins, etc., Increased in seed yield might be due to increased biological nitrogen fixation and solubilisation of more amount of $\mathrm{P}$ by phosphate solubilizing bacteria and improved soil condition favourable for availability of nutrients to crop throughout the growth period. This result is in conformity with the findings of Prajapat et al. (2014). Iraj et al. (2009 also reported that microbial inoculation is highly beneficial to crop growth in higher crop yield. The integration of fertilizers with FYM and vermicompost also gave high yield which was at par with the best treatment. Dabhi (2010) found that application of RDF with FYM significantly produced higher pods plant ${ }^{-1}$ and eventually the grain and stover yields of soybean. However, the lowest seed and stover yield was observed with the application of FYM @ $5 \mathrm{t} \mathrm{ha}^{-1}+$ Vermicompost @ $2 \mathrm{t} \mathrm{ha}^{-1}+$ Rhizobium @ $20 \mathrm{~g} \mathrm{~kg}^{-1}$ seed+Phosphate solubilising bacteria (PSB) @ $20 \mathrm{~g} \mathrm{~kg}^{-1}$ seed which may be due to the low supply of nutrients along with slow release of nutrients for crop growth. Among the different sources of nutrients, highest total nitrogen uptake $(112.32 \mathrm{~kg}$ $\left.\mathrm{ha}^{-1}\right)$, phosphorus uptake (28.69 $\left.\mathrm{kg} \mathrm{ha}^{-1}\right)$ and potassium uptake (64.66 kg ha-1) were recorded with 50\% RDF+Rhizobium @ $20 \mathrm{~g} \mathrm{~kg}^{-1}$ seed+Phosphate solubilising bacteria (PSB) @ $20 \mathrm{~g}$ $\mathrm{kg}^{-1}$ seed which was at par with the treatment $50 \%$ RDF+FYM @ $5 \mathrm{t} \mathrm{ha}^{-1}+$ Vermicompost @ $2 \mathrm{t} \mathrm{ha}^{-1}$. This might due to the increased available phosphorus content of the soil due to inoculation of PSB thereby increasing symbiotic effectiveness of Rhizobium and the amount of nitrogen fixed. This result is in line with work carried by Athul et al. (2008); Sikka et al. (2013). The higher uptake might be due to the P solubilizing microorganisms which in addition to solubilizing $\mathrm{P}$, produce a necessary phytohormone indole acetic acid thereby enhancing root growth and increasing nutrient uptake.

\subsection{Economics as affected by different treatments}

The highest gross return ( $₹ 1,12,000)$, net return ( $₹ 72,554)$ and $B: C(1.83)$ ratio was recorded from the treatment of lime @ $1.5 \mathrm{t} \mathrm{ha}^{-1}$ of lime with 50\% RDF+Rhizobium @ $20 \mathrm{~g} \mathrm{~kg}^{-1}$ 
seed+Phosphate solubilising bacteria (PSB) @ $20 \mathrm{~g} \mathrm{~kg}^{-1}$ seed. The integrated use of inorganic sources of nutrients along with biofertilizers resulted in highest yield of the crop, thereby giving highest net return and B: C ratio. Bhattarcharya et al., 2008 also found that greater productivity and net returns in soybean is obtained through integration of inorganic and organic sources of nutrients along with biofertilizers. Due to the lowest yield obtained under no lime treatment with only organic source of nutrients, the treatment combination gave negative net return and $\mathrm{B}: \mathrm{C}$ ratio.

\section{Conclusion}

Soybean grown in acidic soil having initial $\mathrm{pH}$ value of 4.7 can be amended with $1.5 \mathrm{t}$ of lime ha ${ }^{-1}$ with application of integrated nutrient management 50\% RDF+ Rhizobium @ 20 $\mathrm{g} \mathrm{kg}^{-1}$ seed+Phosphate solubilising bacteria (PSB) @ $20 \mathrm{~g} \mathrm{~kg}^{-1}$ seed for getting better yield and high $\mathrm{B}: \mathrm{C}$ ratio.

\section{References}

Athul, R.S., Joseph, S., Jisha, M.S., 2008. Yield and nutrient uptake of soybean (Glycine max (L.) Merill) as influenced by Phosphate solubilizing microorganisms. World Journal of Agricultural Sciences 4(3), 835-838.

Bambara, S., Ndakidemi, P.A., 2010. The potential roles of lime and molybdenum on the growth, nitrogen fixation and assimilation of metabolites in nodulated legume. A special reference to Phaseolus vulgaris L. African Journal of Biotechnology 8, 2482-2489.

Bekere, W., Kebede, T., Dawud, J., 2013. Growth and nodulation response of soybean (Glycine max L.) to lime, bradyrhizobium japonicum and nitrogen fertilizer in acid soil at Melco, South Western Ethiopia. International Journal of Soil Science 8, 25-31.

Bhattacharjee, S., Singh, A.K., Singh, A.P., Singh, A.K., 2011. Effect of phosphorus, sulphur and cobalt on growth, yield and nutrient content of soybean and soil fertility. Bangladesh Journal of Agriculture and Environment 7 (1), 25-29.

Bhattarcharya, R., Kundu, S., Prakash, R., Gupta, H.S., 2008. Sustainability under combined application of mineral and organic fertilizers in a rainfed soybean-wheat system of the Indian Himalayas. European Journal of Agronomy 28 (1), 33-46.

Bodkhe, A.A., Syed, I., 2014. Effect of bioinoculated and fertilizer levels on growth, yield attributes and yield of soybean (Glycine max (L.) Merill) grown on vertisols. An Asian Journal of Soil Science 9 (1), 63-66.

Chao, S.L., Changli, Z., Yun Hongbing, H., 2014. Impact of animal manure addition on agricultural lime weathering in acidic soil: ph dependence and $\mathrm{CO}_{2}$ independence of agricultural lime weathering. Procedia Earth and Planetary Science 10, 405-409.

Chaturvedi, S., Chandel, A.S., Dhyani, A.S., Singh, A.P., 2010. Productivity, profitability and quality of soybean
(Glycine max) and residual soil fertility as influenced by integrated nutrient management. Indian Journal of Agronomy 55(2), 133-137.

Cochran, W.E., Cox, G.M., 1957. Experimental Designs. Wiley, New York.

Dabhi, B.M., Lokhande, A.K., Polara, J.V., 2010. Effect of integrated nutrient management in soybean (Glycine max). Advances in Plant Science 23 (1), 101-102.

Ellafi, A.M., Gadalla, A., Galal, Y.G.M., 2011. Biofertilizers in action: Contributions of BNF in sustainable agricultural ecosystems. International Science Research Journal 3, 108-116.

Guo, Y.,Yu, N., Ling, Y., Huang, J., 2009. Effects of liming and Sinorhizobium inoculation on growth, nodulation and nutrient concentrations of lucerne in acid soil. Tropical Grasslands 43, 112-117.

Iraj Alahdadi., Masoumeh Tajik., Hamid Iran-Nejad., Omid Armandpisheh., 2009. The effect of biofertilizer on soybean seed vigor and field emergence. Journal of Food and Environment 7(3-4), 420-426.

Kalita, R., Deka, A.K., Azad, P., 2006. Evaluation of native Rhizobium from acid soils of Assam on pigeonpea. Legume Research 29(3), 157-162.

Kiplagat, J.K., Okalebo, J.R., Othieno, C.O., 2010. Determining the appropriate mode and the rate of applying lime to improve maize production in acid soils of north Kakamega and Siaya Districts, Kenya. Second Ruforum biennial meeting 20-24 ${ }^{\text {th }}$ September, 2010, Entebbe, Uganda.

Kisinyo, P.O., Othieno, C.O., Gudu, S.O., Okalebo, J.R., Opala, P.A., Maghanga, J.K., 2013. Phosphorus sorption and lime requirements of maize growing acid soils of Kenya. Sustainable Agriculture Research 2, 116-123.

Mohammadi, K., Sohrabi, Y., Heidari, G., Khalesro, S., Majidi, M., 2012. Effective factors on biological nitrogen fixation. African Journal of Agricultural Research 7, 1782-1788.

Nagar, R.K., Dadheech, R.C., 2002. Response of soybean varieties to Bradyrhizobium under varying nitrogen levels. Haryana Journal of Agronomy 18(1-2), 170-171.

Nagaraju, A.P., Mohan Kumar, H.K., 2010. Effect of micronutrients and bioinoculants on growth and yield of soybean (Gycine max (L.). Mysore Journal of Agricultural Science 44(2), 260-265.

Okpara, D.A., Muoneke, C.O., Hediwa, N., 2007. Influence of liming on the performance of high yielding soybean varieties in South eastern Nigeria. Journal of Agriculture, Food, Environment and Extension 6, 16-24.

Prajapat, K., Vyas, A.K., Shwa, D., 2014. Productivity, profitability and land use efficiency of soybean (Glycine $\max ($ L.) Merrill) based cropping systems under different nutrient management practices. Indian Journal of Agricultural Sciences 59 (2), 229-334.

Rakesh, K., Dibyendu, C., Narendra, K., Avinash, P., Aniruddha, R., Manoj, K., 2014. Productivity, quality and soil health 
as influenced by lime in ricebean cultivars in foothills of northeast India. The Crop Journal 2, 338-344.

Ranjit, R., Dasog, D.S., Patil, P.L., 2007. Effect of lime and phosphorus levels on nutrient uptake by groundnut genotypes in acid soils of coastal agro eco system of Karnataka. Karnataka Journal of Agricultural Sciences. 20 (3), 631-633.

Sikka, R., Singh, D., Deol, J.S., 2013. Productivity and nutrient uptake by soybean as influenced by integrated nutrient and some other agronomic management practices. Legume Research 36(6), 545-551.

Thenua, O.V.S., Kuldeed, S., Shivakumar, B.G., 2010. Studies on Rhizobium inoculation and potassium levels on the performance of soybean (Glycine max L.). Annals of Agricultural Research 31(1), 1-4.

Tomar, R.K.S., 2011. Effect of integration of bio-fertilizers farm yard manure and inorganic fertilizers on productivity of soybean (Glycine max L.) in farmers' field. Journal of Oilseeds Research 28(2), 112-114.

Uzoho, B.U., Osuji, G.E., Onweremadu, E.U., Ibewuchi, I.I., 2010. Maize (Zea mays L.) response to phosphorus and lime on gas flare affected soils. Life Science Journal 7, 77-82.

Verde, B.S., Danga, B.O., Mugwe, J.N., 2013. Effects of manure, lime and mineral $P$ fertilizer on soybean yields and soil fertility in a humic Nitisols in the central highlands of Kenya. International Journal of Agricultural Science Research 2, 283-291.

Walpola, B.C., Yoon, M., 2013. Phosphate solubilizing bacteria: assessment of their effect on growth promotion and phosphorus uptake of mung bean (Vigna radiata [L].R.Wilczek). Chilean Journal of Agricultural Research 73, 275-281.

Wijanarko, A., Taufiq, A., Harnowo, D., 2016. Effect of liming, manure and NPK fertilizer application on growth and yield performance of soybean in Swap land. Journal of Degraded and Mining Land Management 3 (2), 527-533.

Workneh, B., Tesfu, K., Jafer, D., 2013. Growth and nodulation of soybean (Glycine $\max (\mathrm{L}$.) Merrill) to lime, Bradyrhizobium japonicum and nitrogen fertilizer in acid soil at Melko, South Western Ethiopia. International Journal of Soil Science 8, 25-31. 